\title{
Bankruptcy Prediction In The Textile Industry
}

Paula M. Cardwell (E-mail: pcardwell@elon.edu), Elon University, USA Calvert C. McGregor (E-mail: mcgregor@elon.edu), Jr., Elon University, USA Wonhi J. Synn (E-mail: synnwo@elon.edu), Elon University, USA

\begin{abstract}
This paper extends the use of Altman's Z-Score bankruptcy predictor to the textile industry. Generally, firms benefited from the North American Free Trade Agreement (NAFTA) but suffered financially after the Asian currency crisis. The study finds that Type I classification errors support prior research while Type II classification errors are much higher than previous literature findings. The results indicate a need for a modified bankruptcy predictor for the textile industry.
\end{abstract}

\subsection{Introduction}

T

he purpose of this paper is to examine the use of a multiple discriminant analysis (MDA) model, the Altman's Z-Score (Altman, 1968), in predicting bankruptcy in the textile industry. Although much research exists on the application and the success of the Altman's Z-Score, there is no known study related to this industry. The United States textile industry, although facing its worst crisis since the Great Depression, continues to represent one of the largest manufacturing segments in the United States and the leader of textile technological advancements in the world (American Textile Manufacturers Institute, 2002). Therefore, we find it important to examine the financial health of the industry and major textile firms for industry specific improvements to bankruptcy and financial distress prediction.

The results of our study found that the average Z-Score for major textile firms improved (increase) after NAFTA was passed but decreased after the Asian currency crisis in June 1997. In fact, the average Z-Scores for 2000 and 2001 fall in the distressed range. A review of a sample of only bankrupt textile firms supports a high prediction accuracy of the Z-Scores two years prior to bankruptcy filing or a low prediction of nonbankrupt when the firm is actually bankrupt (Type I error). In another sample which included nonbankrupt firms, the prediction of firm bankruptcy when the firm is not bankrupt (Type II error) was significantly higher than Altman's research (Altman, 1993), which is supportive of more recent research (Altman, 2002).

This study contributes to current bankruptcy literature in several ways. First, it uses established publiclytraded textile firms with greater market impact than samples of small firms as used in previous studies. Second, the study samples the major firms in the apparel, floor coverings, home furnishings and the automotive/industrial components of the textile industry. This includes not only bankrupt firms but also nonbankrupt firms. Third, it focuses on an industry that is reported as distressed but to the contrary has currently more nonbankrupt companies than bankrupt ones. Finally, the study supports the original application of the Z-Score for bankruptcy prediction of manufacturers.

The next section provides a brief literature review. The third section describes the sample and methodology. The forth section discusses the research findings. The final section presents our conclusions and opportunities for future research.

Readers with comments or questions are encouraged to contact the authors via email. 


\subsection{Literature Review}

In landmark research by Beaver (1966), individual financial ratios were analyzed to determine the best ratio for predicting failure of a firm. In response to this research, Altman (1968) developed the Z-Score, a MDA) of financial ratios of a firm, as a predictor of bankruptcy. After calculating 22 ratios for a sample of bankrupt and healthy manufacturing firms, the following weighted combination of five ratios performed the best in the prediction of corporate bankruptcy:

$\mathrm{Z}=1.2 \mathrm{X} 1+1.4 \mathrm{X} 2+3.3 \mathrm{X} 3+.6 \mathrm{X} 4+1.0 \mathrm{X} 5$

With

X1 = Working Capital/Total Assets

$\mathrm{X} 2=$ Retained Earnings/Total Assets

X3 = Earnings Before Interest and Taxes/Total Assets

X4 = Market Value Equity/Book Value of Total Debt

$\mathrm{X} 5=$ Sales/Total Assets

The greater the possibility of bankruptcy, the lower a firm's Z-Score. Altman (1968) found that a Z-Score over 2.67 predicted a healthy firm whereas a Z-Score below 1.81 predicted bankruptcy. Z-Scores between 1.81 and 2.67 indicate potential bankruptcy or a grey area. The predictability of Altman's Z-Score was over 80 percent correct for two years prior to bankruptcy but less than half of that for earlier years.

Later research builds upon the MDA to test and offer predictability improvements to the Altman's Z-Score. Deakin (1972) developed a model which was later modified (Nunthaphad, 2000) that included all the ratios identified by Beaver as useful predictors of bankruptcy increasing the bankruptcy predictability to three years. The research is limited by the small sample and the requirement that a specific model needs to be built for each year prior to failure. Edmister (1972) used the financial ratios studied in both the Altman and Beaver research and developed a seven-variable discriminant function model for small firms. Although Edmister uses tri-annual samples, the results support Altman's findings. Blum (1974) developed a "failing company model" based on expected cash flows of large firms for use in the Justice Department. The results were accurate for five years prior to bankruptcy but require a matched validation sample to compare to the test sample. Altman modified his original study. In 1983, Altman substituted the firm's book value of equity for the market value in X4 (Altman, 1983). This resulted in a new ZScore formula where $\mathrm{Z}=.717 \mathrm{X} 1+.847 \mathrm{X} 2+3.107 \mathrm{X} 3+.42 \mathrm{X} 4+.998 \mathrm{X} 5$ and the gray area is 1.23 to 2.90 . Finally in 1993, Altman adjusted the model for nonmanufacturing firms by eliminating the X5 (Sales to Total Assets) variable (Altman, 1993). After a complete reestimation of the model, the revised four-variable model resulted in the following formula: $\mathrm{Z}=6.567 \mathrm{X} 1+3.26 \mathrm{X} 2+6.72 \mathrm{X} 3+1.05 \mathrm{X} 4$. The cutoff for bankruptcy dropped to 1.10 and the gray area became wider to a range of 1.10 to 2.60 . The revised Z-Score is considered only slightly less accurate in terms of Type 1 errors (91\% accuracy rate versus previous 94\%, Altman, 1993).

There are bankruptcy prediction studies other than the MDA models mentioned previously. Although beyond the scope of this paper, a brief mention is needed. Altman et al. (1977) modified the Z-Score by making accounting adjustments to the data and developing a new seven-variable model known as the ZETA model. This model improved the prior bankruptcy prediction accuracy from two years to five years prior to failure. The ZETA model ranks first in accuracy of bankruptcy studies but is a proprietary product only available through ZETA Services, Inc. (Altman, 1993). Other research includes logit and probit analysis or multivariate conditional probability in studies by Ohlson (1980), Zavgren (1985) and Platt and Platt (1990). This research estimates the coefficients that cause patterns in firm and industry bankruptcy data. Although predictive, the patterns must be updated over time resulting in a more complicated model for practitioners to utilize. A more promising area of research is artificial neural networks (ANN). ANN mimic human brain reasoning by training the processing elements to discover patterns and relationships in data (Haykin, 1999). Coats and Fant (1993) and Luther (1998) demonstrate ANN analysis as effective or superior to MDA and logit analysis, respectively. A limitation to ANN is the reliance on the knowledge of experts, who can make varying degrees of Type I and II errors (Altman \& McGough, 1974), to uncover recurring patterns 
and conclusions in bankruptcy prediction decisions. Altman et al. (1994) found problems with the weighting of the indicators but recommended an integrated approach of ANN and MDA for predictive reinforcement.

Due to the popularity, simplicity and accuracy of the Altman's Z-Score, we selected it to predict bankruptcy in the textile industry. As noted previously, research exists for large manufacturing firms, small firms, and private firms. Also, research has focused on MDA both internationally, in countries such as Australia, Brazil, France and others, (Altman, 1993), and in various US industries such as steel (Altman, 1993), savings \& loans (Pantalone \& Platt, 1987), railroads (Altman, 1983), and retail sales (Nunthaphad, 2000).

Past research on textile firm bankruptcy is limited but thought potentially useful. Altman et al. (1974) researched the credit worthiness of loans to cotton and wool textile firms in France, but the results found higher Type I and II errors. Current research is needed. First, it is needed because all bankruptcy is an inefficient use of market and entity resources (Altman, 1984). Second, the threat of bankruptcy in the textile industry may be higher due to the increased debt from expansion into cheaper labor markets, such as Mexico, and technology investments (Burritt, 2000) and the threat from low-priced textile and apparel products of Asian goods (American Textile Manufacturers Institute, August 2001, p. 7). Finally, although the Asian market has helped keep the cost down for consumers in the short run, a smaller domestic textile industry may lead to serious market problems. For example, buyers relying on Asian suppliers and just-in-time inventory practices scrambled for new local suppliers after the September 11 terrorist attacks (Malone, 2001). Therefore, an industry relative approach to the Altman's Z-Score may provide increased accuracy in bankruptcy prediction and assist in financial turnaround for the textile industry.

\subsection{Sample and Methodology}

\subsection{Sample}

One sample consists of: (1) publicly-traded companies with the Standard Institute Classification (SIC) 2211, cotton and woven fabric business identified by Harris InfoSource International, Inc.(Harris InfoSource International (SIC 2211), 2002), (2) The top five publicly-traded firms of each of the 26 SIC codes for textile related businesses over a five year period (Harris InfoSource International, 2002). This search identified 16 companies from SIC 2211 and 22 companies from the SIC code major company list. Six companies were excluded for being either a foreign firm or having no available financial information. To analyze the impact of both NAFTA and the 1997 Asian Crisis, nine years of financial information was obtained through Mergent's FISOnline database (FISOnline, 2002). For companies missing any financial information, SEC filings were used. Of the sample of 32 firms, seven were in Chapter 11 bankruptcy protection.

Another sample of only bankrupt textile firms was selected using BankruptcyData.com (New Generation Research, 2002). Of the 32 listed firms, 15 were excluded for lack of financial information two years prior to bankruptcy or for being out of bankruptcy. Financial information required to calculate the variables in the Altman's Z-Score was obtained for the five years prior to bankruptcy.

\subsection{Methodology}

Much of past research uses multiple regression analysis to study multivariate relationships (Hair et al., 1998). This method does not predict or explain nonmetric variables. MDA estimates the relationship between a nonmetric dependent variable and metric independent variables to find the group to which the dependent variable belongs. MDA requires establishing classification groups, collecting data (financial ratios) for objects (corporations) in the groups, and determining discriminant coefficients or weights. The discriminant coefficients are determined by the variance of variables across the original sample. In order to test the accuracy of Altman's Z-Score in the textile industry, we use the discriminant coefficients of the original Altman (1968) Z-Score and the revised Altman's Z-Score for private firms. The comparison to private firms is helpful for purchases of publicly-traded textile firms by private holding companies and to other existing private textile firms. 
There are several assumptions made in our research about the samples and MDA. We assume the variables are normally distributed and represent a majority of the textile population. This is supported by selecting the largest publicly-traded firms of all textile related SIC codes for the first sample. We also consider the second sample, although a small sample, unbiased because it is selected from a list of all publicly-traded textile bankruptcies since 1988 (New Generation Research, 2002). Other problems with the application of MDA (Eisenbeis, 1977), such as interpretation of individual variables, incorrect or lack of dimension reduction, and poor definition of sampled groups are dealt with in the development and application of the Altman's Z-Score over the years (Altman \& Eisenbeis, 1978; Altman, 1993). There are potential problems with the assessment of the gray zone in our research of bankrupt firms. Not only is the gray zone wide (Clark et al., 1997), the Z-Score user can interpret a Z-Score in this zone to fit their desired results. This is discussed in the next section.

The results for the average annual revised Z-Scores for 1993-2001 are in Table 1. The results show improvement after NAFTA, from 1994 to 1997. In 1998, the average revised Z-Score drops to the lowest level in six years. The Z-Scores improve slightly in 1999 but fall into the gray zone in both 2000 and 2001. This mirrors the trend of the textile relative stock price strength as compared to the Value Line Comparison of 98 industries (Sirois, 2002). The invasion of less expensive Asian consumer products is diminishing the positive effects of NAFTA. Firms, such as Guilford Mills, incurred a lot of debt opening plants and shifting product lines to Mexico only to see China sell products illegally through Mexico prior to being admitted into the World Trade Organization (American Textile Manufacturers Institute, August, 2001). Guilford Mills filed for bankruptcy protection in 2002 and has closed its Mexican plants (Heisler, 2002). On average, the Altman's revised Z-Score is accurate in prediction the textile industry trend. The following discussion reviews the accuracy of the samples for Type I and Type II errors.

\subsection{Summary of Type I \& II Errors} (Table 2):

Altman (1993, p. 204) found the following bankruptcy prediction accuracy of the revised Z-Score Model

Table 2

\section{Classified}

\begin{tabular}{|c|c|c|c|}
\hline Actual & Bankrupt & Nonbankrupt & Total \\
\hline Bankrupt & $\begin{array}{l}30 \\
(90.9 \%)\end{array}$ & $\begin{array}{l}3 \\
(9.1 \%)\end{array}$ & 33 \\
\hline \multicolumn{4}{|c|}{ (Type I) } \\
\hline Nonbankrupt & $\begin{array}{l}1 \\
(3.0 \%)\end{array}$ & $\begin{array}{l}32 \\
(97.0 \%)\end{array}$ & 33 \\
\hline \multicolumn{4}{|c|}{ (Type II) } \\
\hline
\end{tabular}

The results for our sample of 32 textile firms (seven bankrupt and 25 healthy) found the following results for one year (Table 3) and two years (Table 4) prior to bankruptcy:

Table 3: Textile Firm Sample One Year Prior to Bankruptcy

\begin{tabular}{lcllr}
\hline Error Type & $\begin{array}{l}\text { Number } \\
\text { Correct }\end{array}$ & $\begin{array}{l}\text { Percent } \\
\text { Correct }\end{array}$ & $\begin{array}{l}\text { Percent } \\
\text { Error }\end{array}$ & $\begin{array}{l}\text { Sample } \\
\text { Number }\end{array}$ \\
\hline Type I & 32 & 100.00 & 0.00 & 32 \\
Type II & 26 & 81.25 & 18.75 & 32 \\
\hline
\end{tabular}


Table 4: Textile Firm Sample Two Years Prior to Bankruptcy

\begin{tabular}{lcllc}
\hline Error Type & $\begin{array}{l}\text { Number } \\
\text { Correct }\end{array}$ & $\begin{array}{l}\text { Percent } \\
\text { Correct }\end{array}$ & $\begin{array}{l}\text { Percent } \\
\text { Error }\end{array}$ & $\begin{array}{c}\text { Sample } \\
\text { Number }\end{array}$ \\
\hline Type I & 30 & 93.75 & 6.25 & 32 \\
Type II & 27 & 84.38 & 15.63 & 32 \\
\hline
\end{tabular}

Our assumptions about classification of Z-Scores in the gray zone favor the Altman's Z-Score in that we treat Z-Scores for bankrupt firms as accurately predicting if in the gray zone or in the bankruptcy zone. On the other hand, we consider only the bankruptcy zone Z-Score for Type II errors. If these assumptions were reversed, the Type I error rates for one year and two years prior to bankruptcy are $6.25 \%$ and $21.19 \%$, respectively. Whereas the Type II error rates for one year and two years prior to bankruptcy increase to $34.38 \%$ and $31.25 \%$, respectively. The accuracy results support the predictive accuracy of Altman (1993) no matter the assumptions for one year and two years prior to bankruptcy. Before the Type II errors are discussed, the sample results of the bankrupt textile firms are reviewed.

A comparison of original Altman's Z-Score model (Altman, 1968) and our sample of 19 bankrupt textile firms Z-Score classification accuracy is shown in Table 5.

Table 5 Classification Accuracy of Altman and Textile Firm Z-Scores

\begin{tabular}{|c|c|c|c|}
\hline $\begin{array}{l}\text { Years Prior } \\
\text { To Bankruptcy }\end{array}$ & $\frac{1968 \text { Model }}{\text { Bankrupt }}$ & $\frac{\text { Textile Firms }}{\text { Bankrupt }}$ & $\frac{\text { Textile Firms }}{\text { Bankrupt }}$ \\
\hline 1 & 93.9 & 94.7 & 73.7 \\
\hline 2 & 71.9 & 52.6 & 15.8 \\
\hline 3 & 48.3 & 42.1 & 21.1 \\
\hline 4 & 28.6 & 36.8 & 15.8 \\
\hline 5 & 36.0 & 29.4 & 5.9 \\
\hline
\end{tabular}

${ }^{1}$ Assumes that a Z-Score in bankruptcy zone and gray zone predicted bankruptcy.

${ }^{2}$ Assumes that a Z-Score only in bankruptcy zone predicts bankruptcy.

From the above table, the Altman Z-Score one year prior to bankruptcy is an accurate predictor. The results when assuming a Z-Score in the bankruptcy zone and the gray zone predicts bankruptcy is similar to the original Altman (1968) results except for two years prior to bankruptcy. A closer look at textile firms classified as healthy two years prior to bankruptcy finds five of nine firms being healthy two years prior to the Asian currency crisis. If these firms were eliminated the bankruptcies correctly identified, 71.4 percent, are very close to the Altman (1968) results. The second Textile Firms Bankruptcy column highlights the classification of the gray zone again. The next section deals with the false positives (Type II errors), that is, predicted bankruptcies that did not occur.

\subsection{Type II Errors}

As noted above, six companies under the revised Altman's Z-Score are Type II errors one year prior to bankruptcy. This percentage is $15.75 \%$ higher than the original Altman's Z-Score results (Altman, 1968) and double the results of the revised Z-Score (Altman, 1993). Also, two years prior to bankruptcy, five companies are Type II errors, $12.75 \%$ higher than Altman's original research. Altman (1993) refers to this phenomenon as a "staying alive" event by management or creditors and finds that it has increased "as much as $25 \%$ of all firms having Z-Scores" in the bankruptcy zone (Altman, 2002, p. 14). The following is a brief synopsis of the cause of the Type II errors for each textile firm identified. 


\subsection{Collins \& Aikman Corporation}

Collins \& Aikman Corporation (C\&A) is "engaged in the design, engineering and manufacturing of automotive interior components, including instrument panels, fully assembled cockpit modules, floor and acoustic systems, automotive fabric, interior trim and convertible top systems" (The Wall Street Journal Briefing Books, 2003). Through a series of strategic acquisitions, C\&A has "one of the largest interior styling product portfolios in the industry" (Collins \& Aikman, 2002). The C\&A's acquisition of Textron Inc.'s automotive trim unit (TAC-Trim) in December 2001 made C\&A a global leader in the cockpit systems market and the leader in the North American instrument panel market (Collins \& Aikman, 2002). "C\&A instituted a strong restructuring plan and brought in a new team of highly-qualified senior executives from other automotive suppliers...Primarily as a result of these restructuring efforts, C\&A produces five straight quarters of revenue growth through the second quarter of 2000" (Collins \& Aikman, 2002). In 2000, C\&A moved the corporate headquarters from Charlotte, NC to Troy, Michigan to be closer to its customers and the entire automotive industry. Heartland Industrial Partners, L.P., a private equity firm, took majority shareholder status in 2001 through purchasing both newly issued stock and shares from The Blackstone Group and Wasserstein Perella (Collins \& Aikman, 2002). C\&A has continued to "engage in cost-cutting measures that include the shutdown of three money-losing plants in Europe and the elimination of its European corporate headquarters and duplicative infrastructure. The measures also include the closure of three subscale plant operations in North America" (Value Line, 2002).

\subsection{Cone Mills Corporation}

Cone Mills Corporation (Cone) was founded by the Cone brothers in 1891 in Greensboro, North Carolina. It is "the world's largest producer of denim fabrics and the largest commission printer of home furnishings fabric in North America" (Cone Mills Corporation, 2002). Cone is one of the domestic textile companies that have been dramatically affected by Mexican owned textile plants. "Mexico's yearly denim-production capacity has grown from about 150 million yards before NAFTA to more that 450 million yards today . . . The global oversupply had eroded mills' profits by depressing the wholesale price for denim. It sells for $\$ 2.20$ a yard, nearly 27 percent cheaper than four years ago" (Burritt, 2000, p. Q.1). Cone, although reporting losses for four of the last five years, is shutting down unprofitable US operations and investing more cash in a new Mexican factory. Cone has over 4,000 employees at plants in North Carolina, South Carolina and Mexico. Cone sold its converted fabrics operation last year, is looking to sell the khaki business and use the proceeds to pay down debt. Cone continues to remain out of Chapter 11 bankruptcy.

\subsection{Hexcel Corporation}

Hexcel Corporation (Hexcel) is a Connecticut based firm with sales in the commercial aerospace, space and defense, electronics and industrial markets (Hexcel Corporation, 2002). It is tied to the textile industry under SIC code 2295 (Harris InfoSource, 2002), non-rubber coated fabrics, which includes carbon and fiberglass fabrics used in commercial aerospace, space and defense contracts. The firm emerged from Chapter 11 bankruptcy in 1995 by offering additional stock for capital infusion and a merger with the debt ridden composites division of Ciba-Geigy Ltd. Hexcel only moved into the healthy Z-Score zone in 1997 at which time it doubled its debt by purchasing another composites products division. Since 1997, Hexcel had slipped back into the bankruptcy zone by 2001. On December 31, 2001, Hexcel had total liabilities of \$922 million and total assets of \$789.4 million (SEC, 2002). GS Capital Partners, an affiliate of Goldman Sachs, previously purchased 14.5 million shares from Ciba (formerly CibaGeigy)(Investor Group, 2000) and recently agreed along with two other private investment groups, to infuse $\$ 125$ million for convertible preferred stock to help pay maturing debt (Hexcel Corporation, 2002). In addition to the higher debt, the commercial aerospace and electronics industries have faced financial problems which increased Hexcel's financial problems. We would conclude that Hexcel's lack of bankruptcy filing is a result of a combination of questionable past management decisions and owners' hopes of equity preservation to keep the company alive. 


\subsection{Lear Corporation}

Lear Corporation is a Michigan based "automotive supplier to manufacturers around the world, including General Motors, Ford, DaimlerChrysler, BMW, Fiat, Volkswagen, Peugeot, Renault, Toyota and Subaru. The company has established in-house capabilities in all five principal segments of the automotive interior market: seat systems, flooring and acoustic systems, door panels, instrument panels and headliners. The company is also a global supplier of automotive electronic and electrical distribution systems" (The Wall Street Journal Briefing Books, 2003). "Last decade, the company implemented an aggressive acquisition program to widen its footprint into areas such as interiors and electronics. This strategy helped land about $\$ 3.5$ billion in new business for the next five years. However, over the past three years, Lear has stayed away from acquisitions to concentrate on paying down its debt. Indeed, during that time the company reduced its borrowings by over $\$ 1$ billion" (Value Line, 2003). Recently Lear announced signing an innovative contract with General Motors Corp., under which Lear will have complete responsibility for designing and engineering interiors for Buick LeSabre and Cadillac DeVille. The company will also handle purchasing and delivery of the interiors and this "total interior integrator" program is expected to generate an average of $\$ 825$ million in additional annual net sales (Wall Street Journal, January 27, 2003). At the same time, Lear reported record net sales of $\$ 14.4$ billion for the full year of 2002, up $6 \%$ from 2001 , along with a $9.3 \%$ increase in adjusted operating income and a $25 \%$ increase in adjusted earnings per share. The world's largest automotive interior supplier said "it has a $\$ 4$ billion backlog of new business coming on stream in the 2003-2007 period" and "is aiming to reduce its debt load from $58 \%$ of capitalization to a level in the high $40 \%$ range" (Wall Street Journal, January 27, 2003).

\subsection{Playtex Products, Inc.}

Playtex Products, Inc. (Playtex) was in the bankruptcy zone when it went public in 1994 and continues in bankruptcy through 2001. Originally known for its personal care products and plastic gloves, Playtex incurred a heavy debt load to finance a takeover of the company in the late 1980s (Syre \& Nutile, 1994). This debt, at $\$ 841.2$ million in 1994, through additional purchases of other product lines, has continued to remain over $\$ 850$ million. Additional cash infusion has come from a couple of investment groups which own over 50 percent of the stock. Although Playtex has generated net income every year and reduced its negative stockholders' equity, total liabilities have exceeded total assets every year. Although the earnings growth is expected to continue, Playtex is evaluating selling parts or the entire firm to pay down debt (Playtex Products, 2002).

\subsection{Westpoint Stevens, Inc.}

Westpoint Stevens is "the successor corporation to West Point-Pepperell, Inc. through a series of mergers occurring in December 1993." (Westpoint, 2002) Through its various subsidiaries and licensing arrangements, Westpoint Stevens has major market shares in such household products as sheets, pillowcases, towels, and blankets. Over the last several years, the company has implemented a restructuring plan consisting of eight elements designed to "streamline operations and improve profitability." (Westpoint, 2002) The plan includes improvements in inventory management, new market opportunities, savings in logistics and overhead costs. In addition several plants have been closed or scheduled for closing in order to increase the company's efficiency. At the time of this writing, Westpoint Stevens has not filed Chapter 11.

\subsection{Conclusions}

This study examined the use of the Altman's Z-Score in predicting bankruptcy in the textile industry. It was found that the revised Altman's Z-Score accurately predicts firms that are bankrupt in the first and second years prior to the bankruptcy filing. This confirms and extends work previously done by Altman (1993).

The predictability of the Altman's Z-Score is not as accurate for Type II errors when compared to previous research. The six firms described above support the growing prediction of a bankrupt company when it has not filed for bankruptcy (Altman, 2002). Creditors and shareholders wanting to avoid bankruptcy costs and hoping to salvage as much of their investment as possible, oversold leverage buyouts, and management trying to compensate for poor decisions, all are extending the life of some apparently unhealthy firms. 


\subsection{Future Research Applications}

The results show that a bankruptcy tool is useful in identifying unhealthy textile companies. Further research is needed to identify additional measures that more accurately predict and reduce the Type II errors. The answer may be an industry specific model that adds a new variable such as a ratio for textile exports or currency adjustments. A better choice could involve adjusting the discriminant weighting of a current Altman's Z-Score variable, such as X4. Another area for research is the gray zone or, as it was referred to in Altman (1993), the zone of ignorance. As our research shows, there are opportunities for inconsistent interpretation of Z-Scores in this range. The narrower this zone, the greater the accuracy. Finally, additional research as to the utilization of the Altman's Z-Score in the reorganization process of bankrupt textile firms may provide information that will be useful in preventing future bankruptcies.

\section{References}

1. Altman, E. I. (1968). Financial Ratios, Discriminant Analysis and the Prediction of Corporate Bankruptcy. The Journal of Finance, XXIII (4), 589-609.

2. Altman, E. I. (1983). Corporate Financial Distress: A Complete Guide to Predicting, Avoiding, and Dealing with Bankruptcy. New York: John Wiley \& Sons, Inc.

3. Altman, E. I. (1984). A Further Empirical Investigation of the Bankruptcy Cost Question. The Journal of Finance, 39(4), 1067-1089.

4. Altman, E. I. (1993). Corporate Financial Distress and Bankruptcy: A Complete Guide to Predicting \& Avoiding Distress and Profiting from Bankruptcy (2nd ed.). New York: John Wiley \& Sons, Inc.

5. Altman, E. I. (2002). Corporate Distress Prediction Models in a Turbulent Economic and Basel II Environment. In M. Ong (Ed.), Credit Rating: Methodologies, Rationale and Default Risk (p. 1-29). London: Risk Books.

6. Altman, E. I., \& Eisenbeis, R. A. (1978). Financial Applications of Discriminant Analysis: A Clarification. The Journal of Financial and Quantitative Analysis, 13(1), 185-195.

7. Altman, E. I., Haldeman, R. G., \& Narayanan, P. (1977). ZETA Analysis: A New Model to Identify Bankruptcy Risk of Corporations. Journal of Banking and Finance, 1, 29-54.

8. Altman, E. I., Marco, G., \& Varetto, F. (1994). Corporate Distress Diagnosis: Comparisons Using Linear Discriminant Analysis and Neural Networks (the Italian Experience). Journal of Banking and Finance, 18, 505-529.

9. Altman, E. I., Margaine, M., Schlosser, M., \& Vernimmen, P. (1974). Financial and Statistical Analysis for Commercial Loan Evaluation: A French Experience. The Journal of Financial and Quantitative Analysis, 9(2), 195-211.

10. Altman, E. I., \& McGough, T. (1974). Evaluation of a Company as a Going-Concern. Journal of Accountancy, 138(6), 50 .

11. American Textile Manufacturers Institute. (2002). The Textile Crisis. Retrieved February 25, 2002, from http://www.atmi.org

12. American Textile Manufacturers Institute. (August 2001). Crisis in U.S. Textiles. Retrieved February 25, 2002, from http://www.amti.org

13. Beaver, W. H. (1966). Financial Ratios as Predictors of Failures. Empirical Research in Accounting, selected studies, 1966, in supplement to the Journal of Accounting Research (4), 71-111.

14. Blum, M. (1974). Failing Company Discriminant Analysis. Journal of Accounting Research, 12(1), 1-25.

15. Burritt, C. (2000, December 17). Seven Years into NAFTA, Textile Makers Seek Payoff in Mexico Textiles: Payoff Sought in Mexico. The Atlanta Journal the Atlanta Constitution, p. Q.1.

16. Clark, C. E., Foster, P. L., Hogan, K. M., \& Webster, G. H. (1997). Judgmental Approach to Forecasting Bankruptcy. The Journal of Business Forecasting Methods \& Systems, 16(2), 14-18.

17. Coats, P. K., \& Fant, L. F. (1993). Recognizing financial Distress Patterns Using a Neural Network Tool. Financial Management, 22(3), 142-155.

18. Collins \& Aikman Corporation. (2002). Corporate Profile and History. Retrieved February 12, 2003, from http://www.collinsaikman.com

19. Cone Mills Corporation. (2002). History. Retrieved February 25, 2002, from http://www.cone.com 
20. Deakin, E. B. (1972). A Discriminant Analysis of Predictors of Business Failure. Journal of Accounting Research, 10, 167-179.

21. Edmister, R. O. (1972). An Empirical Test of Financial Ratio Analysis for Small Business Failure Prediction. Journal of Financial and Quantitative Analysis, 2, 1477-1493.

22. Eisenbeis, R. A. (1977). Pitfalls in the Application of Discriminant Analysis in Business, Finance, and Economics. The Journal of Finance, 32(3), 875-900.

23. FISOnline. (2002). FISOnline: Company Financials. Retrieved October 5, 2002, from Nova Southeastern University Web Site: http://0-fisonline1.fisonline.com.novacat.nova.edu

24. Hair, Jr., J. F., Anderson, R. E., Tatham, R. L., \& Black, W. C. (1998). Multivariate Data Analysis (5th ed.). Upper Saddle River, NJ: Prentice-Hall, Inc.

25. Harris InfoSource International, Inc. (2002). Textile Manufacturing: Industry Breakdown 1997-2001. Twinsburg, $\mathrm{OH}$.

26. Harris InfoSource International, Inc (SIC 2211). (2002). SIC 2211 Company List. Retrieved June 20, 2002, from http://www.harrisinfo.com

27. Haykin, S. (1999). Neural Networks: A Comprehensive Foundation (2 ed.). Upper Saddle River, NJ: Prentice Hall.

28. Heisler, E. (2002, April 23). Guilford Shuts Plants in Mexico, Lumberton; Before Hard Times Hit, Guilford Mills Had Planned to Invest \$100 Million in the Mexican Industrial Park. Greensboro News Record, p. A1.

29. Hexcel Corporation. (2002). Our Business. Retrieved January 17, 2003, from http://www.hexcel.com

30. Investor Group. Investor Group Led by Goldman Sachs Completes Purchase of Approximately 14.5 Million Shares of Hexcel Common Stock Owned by Ciba Specialty Chemicals. (2000, Dec 19). Business Wire, p. 1.

31. Luther, R. K. (1998). An Artificial Neural Network Approach to Predicting the Outcome of Chapter 11 Bankruptcy. Journal of Business and Economics Studies, 4(1), 57-73.

32. Malone, S. (2001). Mills Seek Solutions to Their Ills; Textile Industry is Having Financial Problems. WWD, 8.

33. New Generation Research, Inc. (2002). Reports-Textiles. Retrieved December 30, 2002, from http://www.bankruptcydata.com

34. Nunthaphad, P. (2000). The Application of Altman's and McGurr's Bankruptcy Prediction Models to Small Retail Firms: A Comparative Analysis. Unpublished Doctoral Dissertation, Nova Southeastern University.

35. Ohlson, J. (1980). Financial Ratios and the Probabilistic Prediction of Bankruptcy. Journal of Accounting Research, 18(1), 109-131.

36. Pantalone, C., \& Platt, M. B. (1987). Predicting Failure of Savings \& Loan Associations. AREUEA, 15(2), 46-64.

37. Platt, H. D., \& Platt, M. B. (1990). Development of a Class of Stable Predictive Variables: The Case of Bankruptcy Prediction. Journal of Business Finance and Accounting, 17(1), 31-51.

38. Playtex Products, Inc. (November 13, 2002). Playtex Products to Evaluate Strategic Alternatives. Retrieved January 27, 2003, from http://www.playtexproductsinc.com

39. Securities and Exchange Commission. (2002, February). Hexcel Corporation and Subsidiaries-10K. Retrieved January 26, 2003, from http://www.sec.gov

40. Sirois, C. (11/15/2002). Industry Report: Textile Industry. The Value Line Investment Survey: Ratings \& Reports, LVIII (11), 1665.

41. Syre, S., \& Nutile, T. (1994, Jan 21). On State Street: Heat's on Lee to Craft Successful IPO for Playtex. Boston Herald, p. 34.

42. Value Line Investment Survey: Ratings and Reports. Collins \& Aikman Corporation (12/6/2002) and Lear Corporation (1/3/2003).

43. Wall Street Journal Briefing Books. (2003). Collins \& Aikman Corporation and Lear Corporation. Retrieved January 21, 2003, from http://www.wsj.com

44. Westpoint Stevens. (2002). Form 10-K for 2001, filed by Westpoint Stevens, Inc. with the Securities and Exchange Commission. Retrieved 2/14/03 via http://www.sec.gov/EDGAR.

45. Zavgren, C. V. (1985). Assessing the Vulnerability to Failure of American Industrial Firms: A Logistic Analysis. Journal of Business Finance and Accounting, 12(1), 19-45. 
Table 1 Average Textile Revised Z-Score By Year

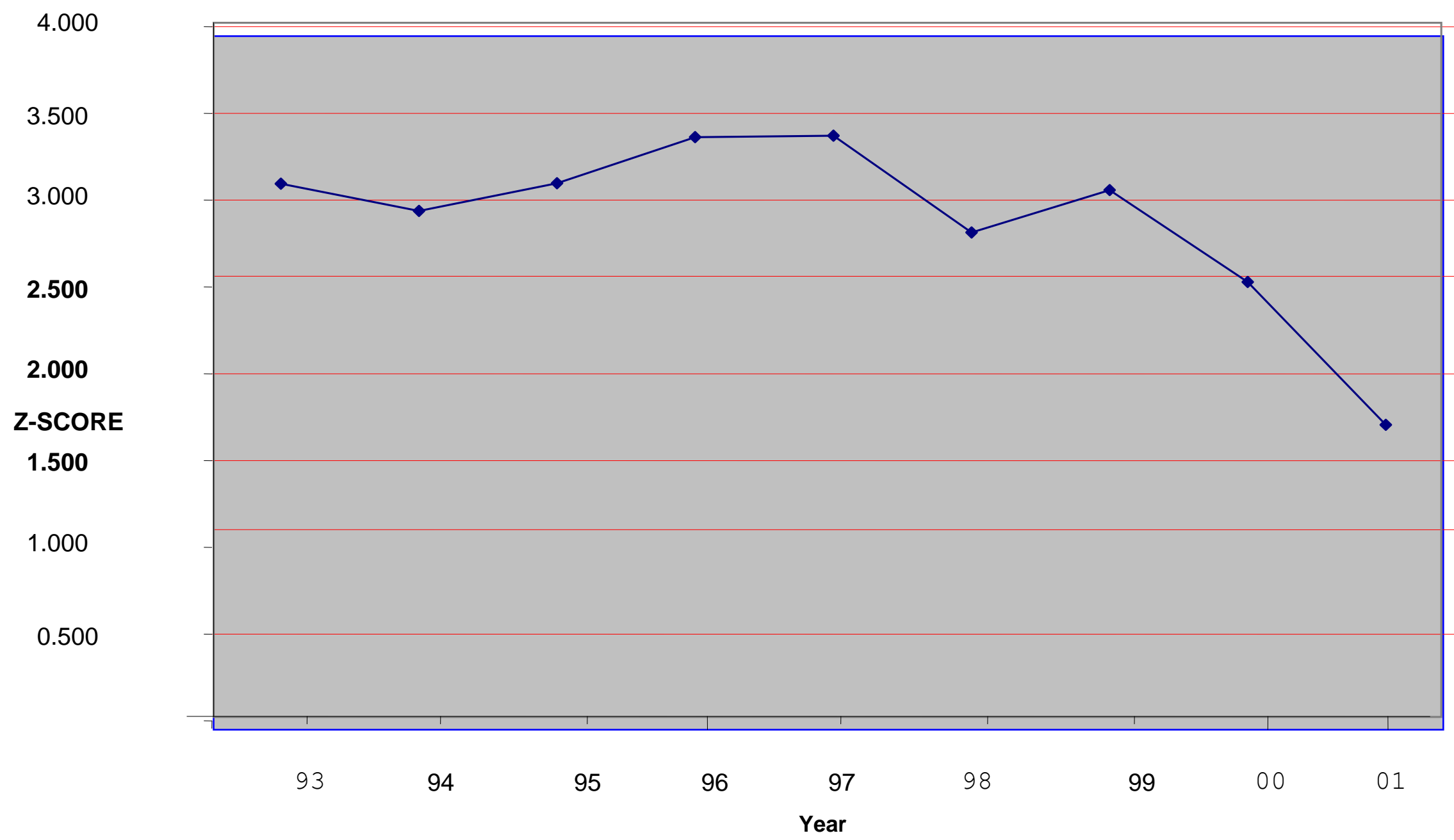

